Biogeosciences Discuss., 6, 9161-9192, 2009

www.biogeosciences-discuss.net/6/9161/2009/

(C) Author(s) 2009. This work is distributed under

\title{
Surface energy exchanges above two grassland ecosystems on the Qinghai-Tibetan Plateau
}

S. Liu ${ }^{1,2}$, S.-G. Li ${ }^{1}$, G.-R. Yu ${ }^{1}$, X.-M. Sun ${ }^{1}$, L.-M. Zhang ${ }^{1}$, Z.-M. Hu ${ }^{1}$, Y.-N. Li ${ }^{3}$, and X.-Z. Zhang ${ }^{4}$

${ }^{1}$ Key Laboratory of Ecosystem Network Observation and Modeling \& Synthesis Research Center of Chinese Ecosystem Research Network, Institute of Geographic Sciences and Natural Resources Research, Chinese Academy of Sciences, Beijing 100101, China

${ }^{2}$ Graduate University of Chinese Academy of Sciences, Beijing 100049, China

${ }^{3}$ Northwest Institute of Plateau Biology, Chinese Academy of Sciences, Xining 810001, China ${ }^{4}$ Key Laboratory of Ecosystem Network Observation and Modeling, Institute of Geographic Sciences and Natural Resources Research, Chinese Academy of Sciences,

Beijing 100101, China

Received: 3 June 2009 - Accepted: 13 August 2009 - Published: 21 September 2009

Correspondence to: S.-G. Li (lisg@igsnrr.ac.cn)

Published by Copernicus Publications on behalf of the European Geosciences Union.

\section{Surface energy grassland ecosystems} exchanges above two

S. Liu et al.

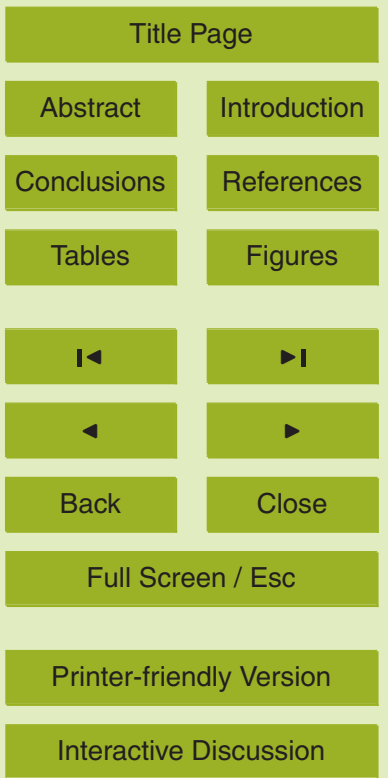




\section{Abstract}

This paper explores the seasonal and inter-annual variations in surface energy exchanges at an alpine shrub-meadow ecosystem (AM) and an alpine meadow-steppe (AS) on the Qinghai-Tibetan Plateau using the 4-5-year continuous flux measurements 5 by the eddy covariance technique. Although ground solar radiation $\left(K_{\mathrm{d}}\right)$ was lower at AM than at AS, net radiation $\left(R_{n}\right)$ was higher at $\mathrm{AM}$ than at $\mathrm{AS}$ due to the lower surface reflectivity for short-wave radiation (albedo) and the lower ratio of upward long-wave radiation to downward long-wave radiation $\left(L_{u} / L_{\mathrm{d}}\right)$ at AM. The ratio of $R_{\mathrm{n}} / K_{\mathrm{d}}$ was lower (about 0.4) at AS than at AM (about 0.6). In the annual scale, annual precipitation was the most important factor controlling energy partitioning at AS, while temperature, especially during the spring, controlled the inter-annual variations in energy partitioning at AM characterized by low temperature. Vegetation growth played an important role in controlling energy partitioning at seasonal scale at both sites. However, soil water content was also one of major factors affecting Bowen ratio $(\beta)$ due to the lower soil water-holding capacity at AS as compared with AM. Under non-drought conditions, the influence of vapor pressure deficit (VPD) on energy partitioning at half-hourly scale was stronger at $\mathrm{AM}$ than at $\mathrm{AS}$ due to higher vegetation cover thereof.

\section{Introduction}

The energy exchange between land surface and the atmosphere is an important process affecting water vapor exchange and carbon sequestration of ecosystems (Ryu et al., 2008), and is critical in driving climate change from the local to even global scales (Raupach, 1998; Cai et al., 2003). The Qinghai-Tibetan Plateau is the highest plateau in the world with a mean altitude of greater than $4000 \mathrm{~m}$ above sea level. It is regarded as a sensitive region to global climate change because of their vastfor the Qinghai-Tibetan Plateau show that the annual mean temperature increased by

BGD

6, 9161-9192, 2009

\section{Surface energy \\ exchanges above two grassland ecosystems}

S. Liu et al.

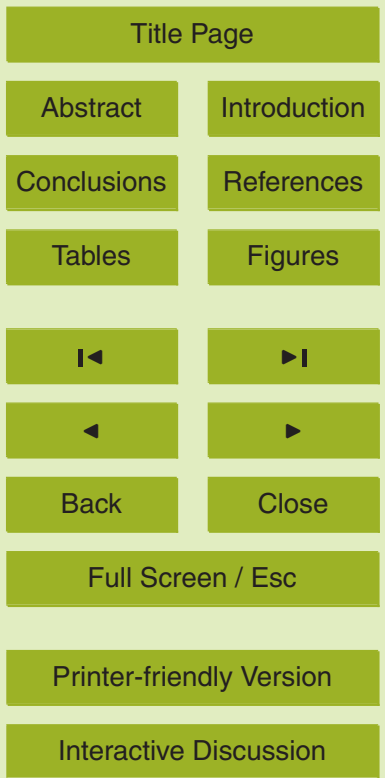


$0.16^{\circ} \mathrm{C}$ per decade and winter temperature increased by $0.32^{\circ} \mathrm{C}$ per decade from 1955 to 1996 , which are higher than the increase in annual mean temperature of the northern hemisphere and at the same latitude due to global climate change (Zheng and Yao, 2006). Climate change has the potential to affect energy, water vapor and carbon 5 dioxide exchanges of the alpine grassland ecosystem on the Qinghai-Tibetan Plateau.

Recently, a large number of studies on energy and water vapor exchanges have been undertaken in many grassland ecosystems. However, most of these studies have been done in savanna areas, temperate grassland in North America and the steppe on the Mongolian Plateau (Baldocchi et al., 2004; Dugas et al., 1999; Wever et al., 2002; Li et 10 al., 2006a; Hao et al., 2007), and only very few studies have focused on the QinghaiTibetan Plateau (Gu et al., 2005; Yao et al., 2008), where alpine grassland occupied more than $60 \%$ of the area (Zheng, 2000). It is reported that soil water content is a major factor affecting the energy partitioning in the alpine meadow ecosystem based on 1-year measurement (Gu et al., 2005). However, plant functional-type, weather, and 15 soil physical properties have a profound effect on water and energy fluxes (Baldocchi et al., 2004), and the shift in vegetation types induced by climate may feed back to regional climate (Eugster et al., 2000; Beringer et al., 2005). A model study has suggested that enhanced warming would cause northward shift of the alpine meadow and a reduction in shrub-dominated alpine steppe on the Qinghai-Tibetan Plateau (Song et 20 al., 2005). Therefore, the study on a variety of vegetation communities with continuous flux measurements will advance our understanding of the energy balance on the Qinghai-Tibetan Plateau which has a complicated landscape.

In this paper, we used 4-5 years continuous flux data measured with the eddy covariance technique, from the ChinaFLUX program (Yu et al., 2006), to explore energy exchanges in an alpine shrub-meadow ecosystem and an alpine meadow-steppe on the Qinghai-Tibetan Plateau. There were big differences in vegetation type and dynamics of soil moisture between these two grassland ecosystems due to the differences in climate and soil properties, which affected the radiation balance and surface exchanges of energy and water vapor. The main objective of this paper was to study

BGD

6, 9161-9192, 2009

\section{Surface energy \\ exchanges above two grassland ecosystems}

S. Liu et al.

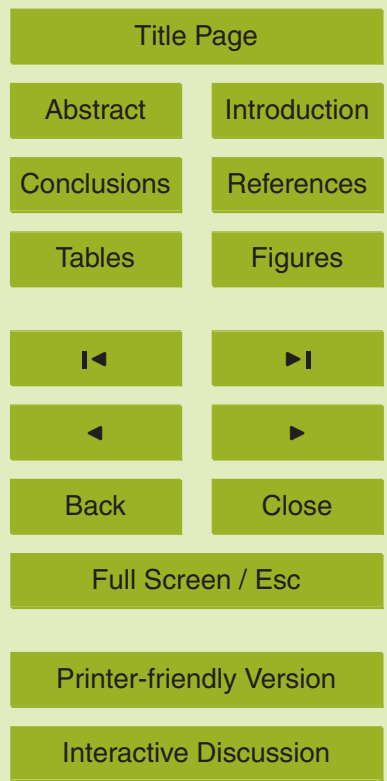


the mechanisms controlling the surface energy exchanges and answer the following two questions:

1. What results in the differences in radiation balance over these two ecosystems?

BGD

2. What are the main variables affecting surface energy partitioning over these two ecosystems?

\section{Materials and methods}

\subsection{Site description}

The research was conducted at two ecosystems representing the most dominant grassland types on the Qinghai-Tibetan Plateau including an alpine shrub-meadow ecosystem at Gancaitan (referred to as AM) and an alpine meadow-steppe ecosystem at Dangxiong (referred to as AS), respectively. The two sites are both located in the western part of China Grassland Transect (CGT) with a humid and semi-humid continental climate. At the AM, the soil type is silty clay loam and the bulk density is $0.98 \mathrm{~g} \mathrm{~cm}^{3}$ for the surface horizon (top $30 \mathrm{~cm}$ ). At AS, the soil type is sandy loam, and there are scattered stones in the surface soil profile and the vegetation growth is limited with nutrients. Table 1 presents more detailed descriptions about climate and vegetation at the sites. Further details can be found in Shi et al. (2006) and Hu et al. (2008).

\subsection{Field measurements}

20 The eddy covariance technique was used to measure the fluxes of carbon dioxide, water vapor, and energy at above-mentioned two grassland ecosystems (Yu et al., 2006). Uniform measurement systems and sensor arrangements were used by the program of Chinese Terrestrial Ecosystem Flux Research Network (ChinaFLUX). It

\section{Surface energy exchanges above two grassland ecosystems}

S. Liu et al.

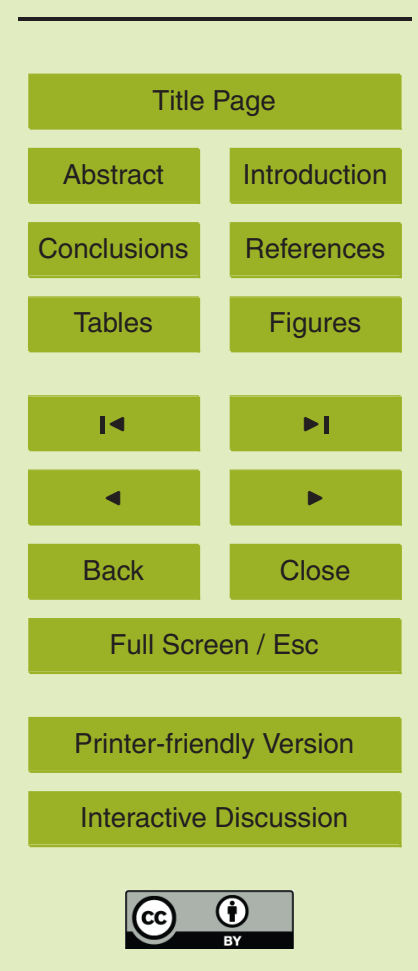


included a three-dimensional sonic anemometer (Model CSAT-3, Campbell Scientific, Logan, Utah, USA) and an open-path $\mathrm{CO}_{2} / \mathrm{H}_{2} \mathrm{O}$ gas analyzer (model LI-7500, Licor Inc., Lincoln, Nebraska). A data logger (Model CSAT-3, Campbell Scientific, Logan, Utah, USA) was used to record the eddy covariance signals with frequency of $10 \mathrm{~Hz}$.

5 All 30 min fluxes were calculated online. We also measured meteorological variables such as air temperature $\left(T_{a}\right)$, relative humidity, precipitation and volumetric soil water content (SWC). Four components of surface radiation balance (up and down long- and short-wave radiation) at each site were measured with the net radiometer (Model CNR1, Kipp \& Zonen, NY, USA). Soil heat fluxes at the depth of $5 \mathrm{~cm}$ were measured by 10 two soil heat plates (HFP01, Hukseflux Inc., Delft, The Netherlands). For details see Yu et al. (2006).

NDVI has been widely used to estimate green biomass and leaf area index (LAI). In this study, NDVI during the growing season (May-September) was used to examine the growth of vegetation (10-day maximum-value composite (MVC) with $1 \mathrm{~km}$ resolution, 15 http://free.vgt.vito.be/index.php) due to the lack of LAI measurements in some years.

\subsection{Data processing}

Three-dimensional rotation was applied to align the coordinate system with the mean wind (Wilczak et al., 2001), and the correction for density effect due to heat and water vapor transfer was made according to Webb et al. (1980) during processing the 20 raw 30-min flux data. When filling missing and spurious data, linear interpolation (for $<2 \mathrm{~h}$ gap) and the mean diurnal variation (MDV) methods were used (Fu et al., 2006). The closure of energy balance is often calculated to assess the performance of the eddy covariance system. There were two studies about the closure of energy balance for sites of ChinaFLUX (Li et al., 2005; Yu et al., 2006), and the energy balance ratio 25 (EBR) of grassland ecosystems ranged between 0.83 and 0.91 (Yu et al., 2006). The imbalance of energy budget may affect the evaluation of sensible heat $(H)$ and latent heat (LE), but it was prevalent in FLUXNET (Wilson et al., 2002).

BGD

6, 9161-9192, 2009

\section{Surface energy \\ exchanges above two grassland ecosystems}

S. Liu et al.

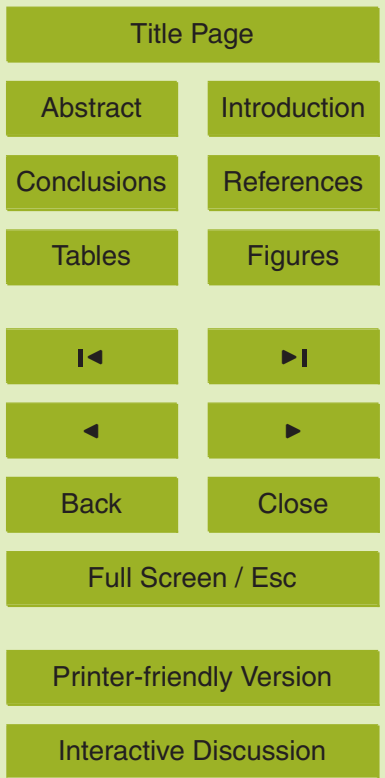




\subsection{Calculations}

Decoupling coefficient $(\Omega)$ and canopy surface conductance $\left(g_{\mathrm{s}}\right)$ were calculated to assess the effect of physiological and environmental factors on water vapor exchange. The half-hourly $g_{\mathrm{s}}$ was derived from the Penman-Monteith equation (Monteith and 5 Unsworth, 1990):

$$
\frac{1}{g_{\mathrm{s}}}=\frac{\rho C_{p} \operatorname{VPD}}{\gamma L E}+\frac{\frac{\Delta\left(R_{\mathrm{n}}-G-L E\right)}{\gamma L E}-1}{g_{\mathrm{a}}},
$$

where $\rho, C_{p}$ and VPD are the air density $\left(\mathrm{kg} \mathrm{m}^{-3}\right)$, the specific heat of air $\left(\mathrm{J} \mathrm{kg}^{-1} \mathrm{~K}^{-1}\right)$ and the atmospheric saturation vapor pressure deficit $(\mathrm{kPa})$, respectively. And $\gamma$ is the psychrometric constant $\left(\mathrm{kPaK}^{-1}\right), \Delta$ is the slope of saturation vapor pressure as a function of air temperature $\left(\mathrm{kPa} \mathrm{K}^{-1}\right)$, and $g_{\mathrm{a}}$ is the aerodynamic conductance $\left(\mathrm{m} \mathrm{s}^{-1}\right)$ which is computed with the method described by Lloyd (1995). $R_{\mathrm{n}}$ and $L E$ is net radiation and latent heat flux $\left(\mathrm{Wm}^{-2}\right)$, respectively, and $G$ is soil heat flux $\left(\mathrm{Wm}^{-2}\right)$.

The dimensionless $\Omega$ was computed by:

$$
\Omega=\frac{\Delta+\gamma}{\Delta+\gamma\left(1+\frac{g_{\mathrm{a}}}{g_{\mathrm{s}}}\right)},
$$

15 In calculation of $g_{\mathrm{s}}$ and $\Omega$, only midday values (09:00 to 16:00) were used and those obtained during the time periods with recorded precipitation, inadequate turbulence $\left(u^{*}<0.1 \mathrm{~m} \mathrm{~s}^{-1}\right)$ and low PAR (PAR $\left.<25 \mu \mathrm{mol}^{-2} \mathrm{~s}^{-1}\right)$ were excluded (Wever et al., 2002).

In addition, the daily mean reflectivity of short-wave radiation at the surface (albedo) is the average when downward short-wave radiation $>200 \mathrm{~W} \mathrm{~m}^{-2}$ to minimize the effect of low solar angles (Li et al., 2006a).

BGD

6, 9161-9192, 2009

\section{Surface energy exchanges above two grassland ecosystems}

S. Liu et al.

\section{Title Page}

Abstract Introduction

Conclusions

Tables References Figures

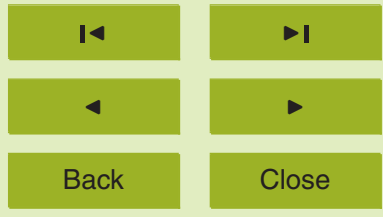

Full Screen / Esc

Printer-friendly Version

Interactive Discussion 


\section{Results and discussion}

\subsection{Climate conditions and vegetation development}

The seasonal and inter-annual variations in $T_{\mathrm{a}}$, VPD, wind speed at $2.2 \mathrm{~m}(u)$, SWC and precipitation are shown in Fig. 1. The seasonal variation of $T_{a}$ at two ecosystems 5 showed similar pattern, while $T_{a}$ was usually higher at AS than at AM. Both VPD and $u$ in the growing season were larger at AS than at AM. The mean annual precipitation during the study periods was $507 \pm 33 \mathrm{~mm}$ at $A M$ and $418 \pm 130 \mathrm{~mm}$ at $A S$, respectively. SWC was lower at AS due to the lower soil water-holding capacity. Inter-annual comparison of $T_{\mathrm{a}}$ and precipitation in the growing season at AM and AS are shown in Table

102 . The precipitation in the growing season of 2006 (only $207 \mathrm{~mm}$ ) was significantly lower than the average $(480 \mathrm{~mm})$ at AS.

Seasonal and inter-annual variations in NDVI are shown in Fig. 2. The NDVI was generally lower and its inter-annual and intra-seasonal variations were higher at AS than at AM. The mean NDVI in the growing season was 0.27 in 2004 and 2005, higher tion at AS (Table 2). The average NDVI in May of 2007 was higher than those of other four years at AM. This is likely due to higher temperature observed in May of 2007 that enhanced plant growth. The average temperature in May of 2007 was $5.33^{\circ} \mathrm{C}$, while it ranged from $-0.22^{\circ} \mathrm{C}$ to $3.05^{\circ} \mathrm{C}$ during the previous four years. Yang and Piao (2006) suggested that the largest NDVI increase during the growing season occurred in the spring is due to the advanced growing season and accelerated vegetation activity for the grasslands on the Tibetan Plateau.

\subsection{Seasonal and inter-annual variations in energy fluxes and albedo}

For the homogenous grassland ecosystems, net radiation $\left(R_{\mathrm{n}}\right)$ at the canopy surface
BGD

6, 9161-9192, 2009

\section{Surface energy}

exchanges above two grassland ecosystems

S. Liu et al.

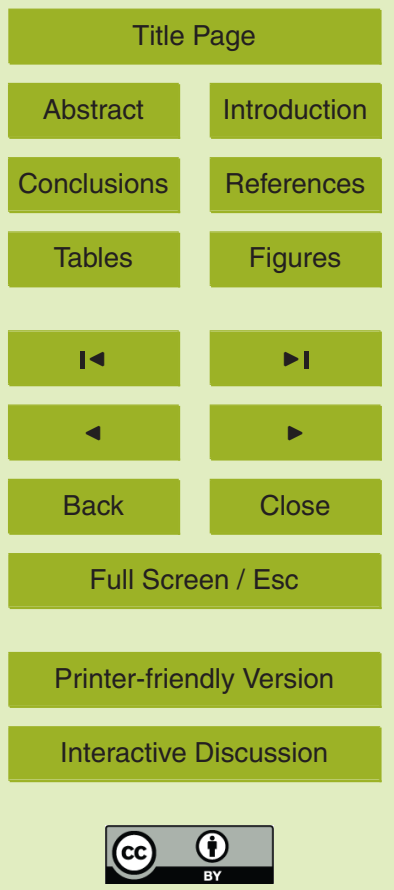


where $K$ and $L$ represent the short-wave radiation and long-wave radiation, respectively. And subscript $\mathrm{n}, \mathrm{d}$ and $\mathrm{u}$ represent net, downward, and upward directions, respectively. Figure 3 shows the seasonal and inter-annual courses of $K_{\mathrm{d}}$ and $R_{\mathrm{n}}$. Their seasonal pattern was similar at both sites. $K_{d}$ was higher at AS than at AM and the 5 total $K_{\mathrm{d}}$ in the growing season (May-September) was $3331.9 \pm 90.5 \mathrm{MJ} \mathrm{m}^{-2}$ at AS, and $3023.6 \pm 31.6 \mathrm{MJ} \mathrm{m}^{-2}$ at $\mathrm{AM}$, respectively. However, $R_{\mathrm{n}}$ of $\mathrm{AM}\left(1824.9 \pm 36.2 \mathrm{MJ} \mathrm{m}^{-2}\right)$ was generatively higher than that of $A S\left(1462.8 \pm 89.5 \mathrm{MJ} \mathrm{m}^{-2}\right)$ in the growing season. The ratio of $R_{\mathrm{n}} / K_{\mathrm{d}}$ was about 0.4 at AS, but 0.6 at AM. The mean albedo $\left(=K_{\mathrm{u}} / K_{\mathrm{d}}\right)$ and $L_{u} / L_{d}$ ratio at $A M$ in the growing season were $0.12 \pm 0.01$ and $1.23 \pm 0.02$, respectively, 10 both being lower than those of $A S\left(0.17 \pm 0.01\right.$ for $K_{u} / K_{d}$ and $1.33 \pm 0.04$ for $\left.L_{u} / L_{d}\right)$. The ratio of net long-wave radiation to net short-wave radiation was $31.1 \%$ at $A S$ and $46.6 \%$ at AM, respectively. The lower albedo and lower $L_{u} / L_{d}$ were responsible for higher $R_{n}$ at $A M$ relative to the $A S$.

Seasonal variations in the daily albedo during the growing season are shown in 15 Fig. 4. Daily albedo varied from 0.08 to 0.15 at $A M$, and relatively very high (very low) albedo was observed after heavy snowfall (after strong rainfall) (Fig. 4). The albedo at $\mathrm{AM}$ was close to that of European sub-alpine wet grassland ecosystems (0.11 in August and September) (Rosset et al., 2001). The daily albedo was usually higher at AS than at $\mathrm{AM}$, ranging from 0.12 to 0.23 , which was close to those of an European grass20 land ecosystems (0.17-0.19) at the same latitude (Rosset et al., 1997), and a central Mongolian steppe (0.13-0.26) ( $\mathrm{Li}$ et al., 2006a). The variation of albedo was closely associated with the variation of SWC and the vegetation status (Li et al., 2006a). For example, a significant linear relationship at AS was found between albedo and SWC at the $20 \mathrm{~cm}$ depth (SWC in \%) (albedo=-0.003 SWC+(0.208 \pm 0.002$), n=591$, adjusted $\left.25 R^{2}=0.504, F=602.27, P<0.0001\right)$. Gu et al. (2005) suggested that the high summertime albedo may favor alpine plants to avoid the high radiation stress on the plateau. By contrast, albedo was lower at AM compared with another meadow ecosystem nearby $(0.16-0.26)\left(37^{\circ} 36^{\prime} \mathrm{N}, 101^{\circ} 18^{\prime} \mathrm{E}\right)$ (Gu et al., 2005). This may be due to higher SWC and higher vegetation cover at AM.

BGD

6, 9161-9192, 2009

\section{Surface energy \\ exchanges above two grassland ecosystems}

S. Liu et al.

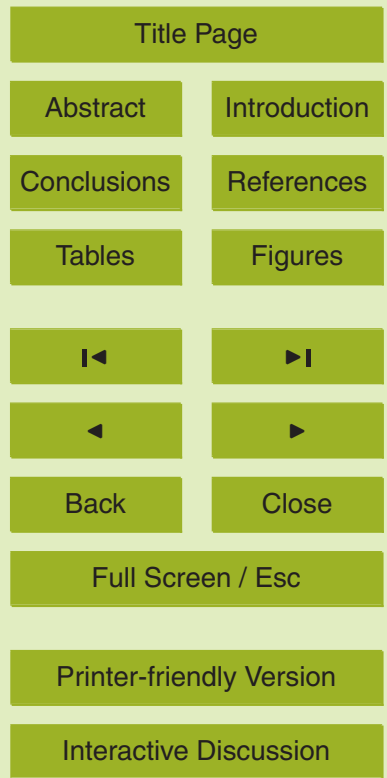


Figure 5 shows the seasonal variations of sensible heat $(H), L E$ and $G$. The highest $H$ values were often observed from mid April to mid June at both sites. With the increase of rainfall and growth of vegetation, $L E$ increased gradually while $H$ decreased. The $H$ increased again after the peak growth. $H$ was generally higher at AM than at 5 AS (Fig. 5). LE was higher in May at AM than at AS due to the higher SWC at AM than at AS. The seasonal pattern of $G$ was similar at both sites. $G$ was usually negative from early November to early February, indicating that the ground was energy source for the atmosphere. Gwas generally higher at AS than at AM from late February to late March, which was consistent with the seasonal variation of $K_{\mathrm{d}}$ (Fig. 3). During the 10 study periods, average value of $G / R_{\mathrm{n}}$ in the growing season at both sites kept almost constant of about 0.04 .

\subsection{Comparison of inter-annual variations in the Bowen ratio between two ecosystems}

The Bowen ratio $(\beta=H / L E)$ is widely used for comparing the energy partitioning among different ecosystems (Wilson et al., 2002). The inter-annual variations in $\beta$ were low at AM, ranging between 0.55 and 0.68 . Similarly, $T_{\mathrm{a}}$, NDVI and canopy surface conductance $\left(g_{\mathrm{s}}\right)$ varied little inter-annually at AM (Table 2). The average $\beta$ in the growing season of 2007 was lowest, which may stem from the abnormal high temperature in May as mentioned above (Sect. 3.1). The AM ecosystem is characterized by low temperature (Table 1). More water vapor was evapotranspirated with the advanced vegetation growth under the conditions of warm spring in 2007 at AM. The amount of ET was $95 \mathrm{~mm}$ in May of 2007, higher than previous four years (varied from 54 to $60 \mathrm{~mm}$ ). By contrast, at AS, $\beta$ varied from 0.37 (2004) to 0.66 (2006), being consistent with the wide variation in precipitation, indicating that water availability controls the energy partitioning at inter-annual scale.

Wilson et al. (2002) suggested that the large variability of $\beta(0.34-1.91)$ between sites and years at grassland can be explained by two reasons: at first, the grassland ecosystem is highly sensitive to human disturbance (e.g. grazing); and secondly it is
BGD

6, 9161-9192, 2009

\section{Surface energy \\ exchanges above two grassland ecosystems}

S. Liu et al.

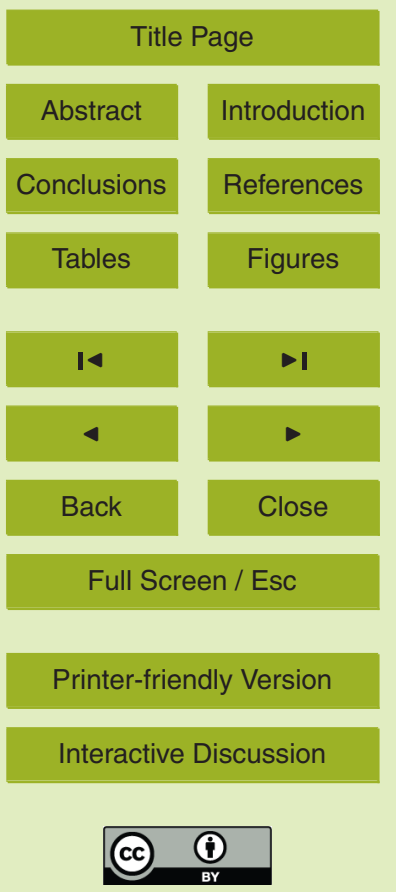


more sensitive to soil moisture than shrubs and forests due to the difference in the ability of roots to access deep soil water. In this study, the difference of $\beta$ at two sites can be explained by climate, soil type and vegetation. On the one hand, Indian monsoon has a greater influence on precipitation in the south of the Qinghai-Tibetan

5 Plateau (Tian et al., 2001). During the study periods, the coefficient of variation of the annual precipitation was $31.1 \%$ at $\mathrm{AS}$, higher than that at $\mathrm{AM}(6.5 \%)$. On the other hand, soil water-holding capacity was lower at AS than at AM. In addition, root mass was mainly distributed in the soil layer of $0-10 \mathrm{~cm}$ at $A S$, while it was in $0-40 \mathrm{~cm}$ depth at AM (Li et al., 2006b), resulting in further intensification of water limitation at AS.

The vegetation distribution may change due to the climate change on the QinghaiTibetan Plateau (Song et al., 2005). However, more attention should be given to the effect of grazing. On the Qinghai-Tibetan Plateau, a large area of grassland has been degraded in the past few decades because of overgrazing (Cui et al., 2007), e.g. the AS site in this study. Bremer et al. (2001) suggested that grazing decreased ET, and thus the $\beta$ increased. The increase in $\beta$ indicates a higher fraction of available energy $\left(R_{\mathrm{n}}-G\right)$ is partitioned into $H$ which will cause a positive feedback to atmospheric temperature. Eugster et al. (2000) suggested that the vegetation change from tundra to shrub or shrub to forest in arctic would cause a negative feedback because forests had a lower ET rate, which reduced the water vapor flux to the atmosphere as a strong greenhouse gas. There was little information about effect of vegetation change on ET on the Qinghai-Tibetan Plateau. From our study, we learned that a conversion from AM to AS or vice versa would alter surface energy balance and the partitioning of the available energy though the change of surface albedo, giving rise to a change in local or even regional climate. However, there was still some uncertainty about climate change and the feedback from vegetation change on the Qinghai-Tibetan Plateau. This deserves further study in the future.
BGD

6, 9161-9192, 2009

\section{Surface energy \\ exchanges above two grassland ecosystems}

S. Liu et al.

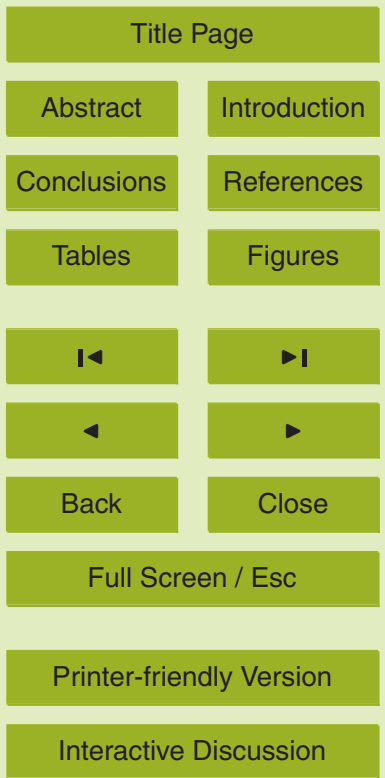




\subsection{Comparison of seasonal variations in the Bowen ratio between two ecosys- tems}

BGD

The seasonal variation of daily $\beta$ during the growing season at AM and AS is shown in Fig. $6 a$, exhibiting a reverse trend with plant growth. However, the range of variations 5 in daily $\beta$ was larger and the values of $\beta$ often increased markedly when the SWC was low at $A S$ versus at $A M$, which was consistent with the seasonal variation of daily surface conductance $\left(g_{\mathrm{s}}\right)$ during the growing season (Fig. 6b). At both sites, the $g_{\mathrm{s}}$ was relatively high when NDVI was high and soil was moist. The maximum daily average $g_{\mathrm{s}}$ could reach about $20 \mathrm{~mm} \mathrm{~s}^{-1}$ at both sites, close to that of an annual grassland 10 ecosystem in California (Ryu et al., 2008), and higher than that of temperate grassland in Canada ( $\sim 9 \mathrm{~mm} \mathrm{~s}^{-1}$, lower in droughty year) (Wever et al., 2002).

Figure 7 illustrates the relationship between the monthly average $\beta$ and NDVI, surface conductance $\left(g_{\mathrm{s}}\right)$ at AM and AS. With the increase of $g_{\mathrm{s}}$ and NDVI, indicative of the growth status of vegetation, $\beta$ decreased, indicating that more water vapor was evapotranspirated into the atmosphere. The seasonal pattern of $\beta$ suggests that the phenology of the vegetation was the major factor affecting the energy partitioning at both sites at intra-seasonal scale. This is consistent with previous studies in that vegetation characteristics strongly influence the energy partitioning (e.g. Li et al., 2006a; Hammerle et al., 2008).

20 The growth of vegetation not only affects the energy partitioning, but also has great influence on partitioning of evapotranspiration into its components (plant transpiration and soil evaporation). Hu et al. (2009) suggested that the variations in LAI could cause stronger effects on the ratio of evaporation $(E)$ to evapotranspiration $(E T)$ in the sparsecanopy ecosystems than in the dense-canopy ecosystems. It was found that E/ET in 25 the growing season was above $58 \%$ at AS, and only about $42 \%$ at AM, respectively (Hu et al., 2009).

Figure 8 shows the relationship between the daily average $\beta$ and SWC at AM and AS. $\beta$ decreased with the increase of SWC at AS. However, there was no significant

\section{Surface energy \\ exchanges above two grassland ecosystems}

S. Liu et al.

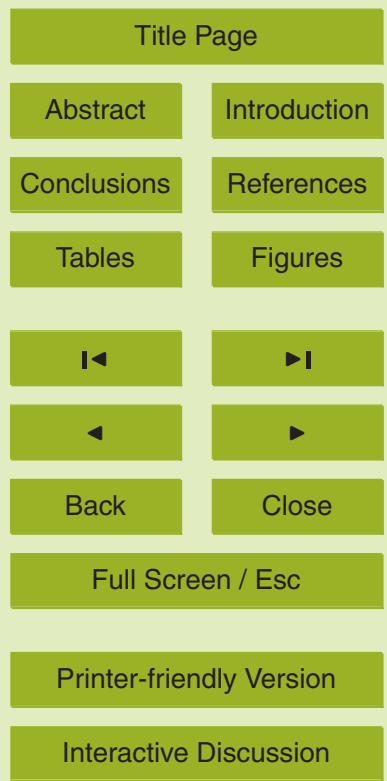


correlation at $\mathrm{AM}$ because water availability was not the limiting factor of energy partitioning.

Previous studies have shown that soil moisture is an important factor affecting energy partitioning, particularly in arid and semi-arid areas. For example, $\beta$ decrease 5 with the increase of SWC after the precipitation events over the semi-arid grassland ecosystems on the Mongolian plateau (Hao et al., 2007; Li et al., 2006a). Gu et al. (2005) also suggested that soil moisture was an important factor affecting the energy partitioning in another alpine meadow ecosystem dominated by Kobresia humilis close to AM. However, soil water was not the limiting factor of evapotranspiration at AM. It 10 can be explained by the big differences in soil type (Mat-Cryic Cambisol at Gu et al. (2005), Mol-Cryic Cambisols at AM) and vegetation type between these two ecosystems resulted from the different direction and gradient of slope.

\subsection{Comparison of biophysical control on energy partitioning at half-hourly scale between two ecosystems}

15 Energy partitioning is principally associated with the complicated interaction between biotic and abiotic variables such as green leaf area index, plant functional type, net radiation, soil moisture availability and vapor pressure deficit (VPD) (Gu et al., 2006; Li et al., 2006a). However, effects of these factors on $\beta$ are different at different time scales, e.g. LAI and SWC varied little at a 30-min resolution while $R_{\mathrm{n}}$ and VPD varied more at 20 a 30-min than at a daily scale. To further understand the mechanisms controlling the surface energy exchanges at two ecosystems, the effects of $R_{\mathrm{n}}$ and VPD on energy partitioning were analyzed at half-hourly time step.

\subsubsection{Effect of net radiation}

The Bowen ratio slightly increased with $R_{\mathrm{n}}$ at both sites (Fig. 9), but drought increased the range of variation at AS (Fig. 9a) which was similar to that at a temperate forest ecosystem (Gu et al., 2006). It is well known that both $H$ and $L E$ increase with $R_{\mathrm{n}}$;

\section{Surface energy exchanges above two grassland ecosystems}

S. Liu et al.

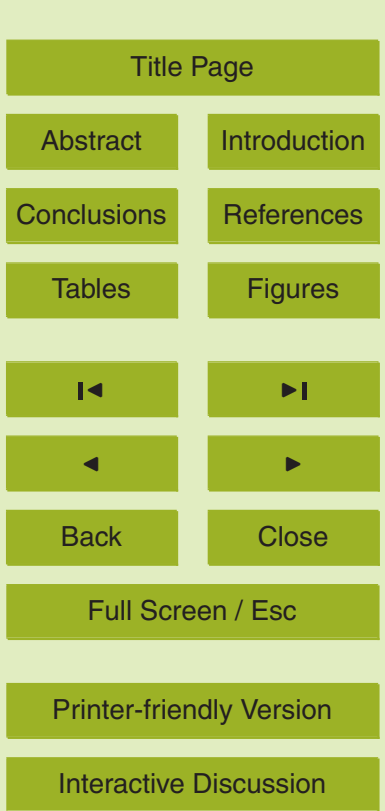


however, their increases are not in proportion because $L E$ is limited by the amount of water available in the soil and stomatal openness (Gu et al., 2006). Therefore, $\beta$ tends to increase with the increase of $R_{\mathrm{n}}$ at $\mathrm{AS}$ and $\mathrm{AM}$, and the trend was stronger under the conditions of drought at AS (Fig. 9a).

5 Gu et al. (2006) suggested that the difference in the Bowen ratio between drought and non-drought conditions increased with $R_{\mathrm{n}}$ and VPD because more available energy was partitioned into $L E$ with the increase of $R_{\mathrm{n}}$, and this trend was intensified at higher levels of VPD. However, in this study, there was no significant difference in effects of $R_{\mathrm{n}}$ on $\beta$ at two levels of VPD $(<1 \mathrm{kPa}$ and $>1 \mathrm{kPa})$ no matter what soil moisture 10 conditions at AS and AM (data not shown), which means that the effect of $R_{\mathrm{n}}$ on $\beta$ did not depend sensitively on VPD. This may be related to the low values of VPD at both sites (generally below $1.5 \mathrm{kPa}$ ).

\subsubsection{Effect of vapor pressure deficit}

Figure 10 shows the effect of VPD on energy partitioning at two levels of SWC (non15 drought and drought) at AS. Under non-drought conditions, there was no distinct effect of VPD on $\beta$ at AS (Figures 10a), but $\beta$ increased with increased VPD under drought conditions (Fig. 10b). In addition, the effect of VPD on $\beta$ with different levels of $R_{\mathrm{n}}$ can be ignored under all levels of soil moisture (data not shown). The effects of VPD on energy partitioning at two levels of $R_{\mathrm{n}}\left(<250 \mathrm{Wm}^{-2}\right.$ and $\left.>500 \mathrm{Wm}^{-2}\right)$ at AM was shown 20 in Fig. 11. Overall, $\beta$ decreased with the increased VPD at AM, but the decrease was sharper at high levels of $R_{\mathrm{n}}\left(>500 \mathrm{Wm}^{-2}\right)$ (Fig. 11b). And the effect of $R_{\mathrm{n}}$ between $250 \mathrm{Wm}^{-2}$ and $500 \mathrm{Wm}^{-2}$ was medium (data not shown) at AM.

The influence of VPD on energy partitioning was stronger at AM than at AS under non-drought conditions (Figs. 10a and 11), and it was nonlinear at AM (Fig. 11). What caused the difference in effect of VPD on $\beta$ at AS and AM? Studies showed that the nonlinear effect of VPD on $\beta$ stems from two simultaneous but opposing effects of VPD on $L E$ : on the one hand, $L E$ increased with the increased VPD driving more water vapor out of the stomatal pore; on the other hand, high VPD reduced the stomatal

\section{BGD}

6, 9161-9192, 2009

\section{Surface energy \\ exchanges above two grassland ecosystems}

S. Liu et al.

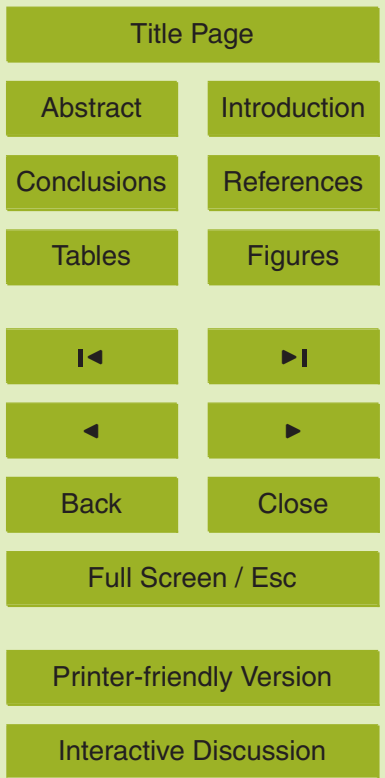


conductance limiting the $L E$ (Ball et al., 1987). The positive effect of increased VPD outweighs its negative effect on LE when VPD is low (Gu et al., 2006), which explained why $\beta$ decreased with the increased VPD at AM. Soil evaporation dominated the evapotranspiration at AS as mentioned above due to low LAI (Hu et al., 2009). Therefore, 5 the effect of VPD on stomatal conductance was weaker at AS versus at AM. Further, there was a high correlation between high VPD and severe drought resulting in more available energy was partitioned into $H$, and thus increased $\beta$ at AS (like Fig. 10b). Therefore, the difference in effect of VPD on $\beta$ resulted from the difference in vegetation cover between two sites.

The decoupling coefficient $(\Omega)$ is often used to separate the effect of VPD on LE from $R_{\mathrm{n}}$ (Gu et al., 2005; Hao et al., 2007). $\Omega$ varies from 0 to 1. A low $\Omega$ indicates a relatively high influence of VPD on ET, and a high $\Omega$ suggests that $R_{\mathrm{n}}$ exerts the dominant influence on ET (Jarvis and McNaughton, 1986). The values of $\Omega$ were often over 0.7 during the peak growth stage at both sites (not shown in this paper), implying that evapotranspiration process at two sites is coupled to the radiation forcing. However, $\Omega$ was low during the dry period at AS (e.g. in August 2006 and May-June in 2007), which indicates that the control of VPD on LE was strengthened.

Surface conductance $\left(g_{\mathrm{s}}\right)$ and aerodynamic conductance $\left(g_{\mathrm{a}}\right)$ are two parameters determining $\Omega$ directly. Here, the effects of $g_{\mathrm{s}}$ and $g_{\mathrm{a}}$ on $\Omega$ were discussed with the data of 2004 at half-hourly scale. The dependencies of $\Omega$ on $g_{\mathrm{a}}$ and $g_{\mathrm{s}}$ were in opposite directions (Fig. 12). As $g_{\mathrm{a}}$ decreased and $g_{\mathrm{s}}$ increased, thus $\Omega$ increased, suggesting that evapotranspiration became more coupled with radiation forcing. The magnitude of $g_{\mathrm{a}}$ depends on the aerodynamic properties (e.g. wind speed and roughness) of the surface. The wind speed was larger, resulting in lower $g_{\mathrm{a}}$ at AS compared with AM. 25 Therefore, the value of $\Omega$ was higher in 2004 at AS than AM (Table 2) due to the lower $g_{\mathrm{a}}$ and higher $g_{\mathrm{s}}$.

BGD

6, 9161-9192, 2009

\section{Surface energy \\ exchanges above two grassland ecosystems}

S. Liu et al.

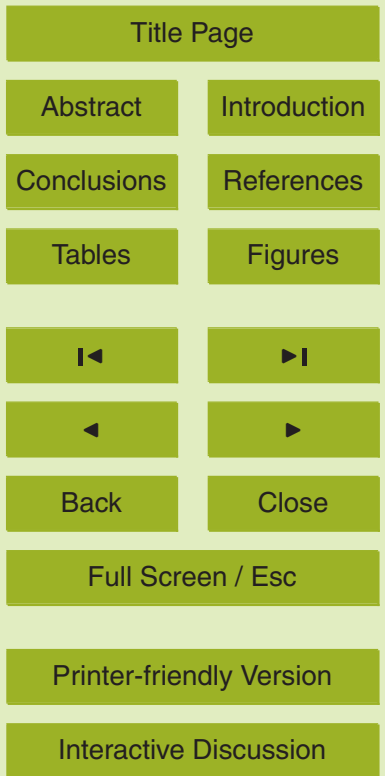




\section{Summary}

The seasonal and inter-annual variations in surface energy exchanges at two grassland ecosystems on the Qinghai-Tibetan Plateau were explored. Relative to the alpine meadow-steppe (AS), solar radiation $\left(K_{\mathrm{d}}\right)$ was lower, but net radiation $\left(R_{\mathrm{n}}\right)$ was higher 5 at the alpine shrub-meadow ecosystem (AM). This is because the surface reflectivity for short-wave radiation (albedo) and the ratio of upward long-wave radiation to downward long-wave radiation $\left(L_{u} / L_{d}\right)$ were lower at AM as compared with AS. During the growing season, daily albedo varied from 0.08 to 0.15 at $A M$ and from 0.12 and 0.23 at AS in response to variations of NDVI and soil moisture. It decreased significantly with

10 the increase of SWC at AS. The mean $L_{u} / L_{d}$ ratio in the growing season was 1.23 at $A M$ and 1.33 at $A S$, respectively.

In the annual scale, annual precipitation was the most important factor controlling energy partitioning at $A S$, while temperature of May controlled the inter-annual variations in the Bowen ratio $(\beta)$ at AM which is characterized by low temperature. Vegetation 15 growth played an important role in controlling energy partitioning at seasonal scale at both sites. However, abnormally high $\beta$ often occurred during the growing season under the drought conditions due to the low soil water-holding capacity at AS as compared with AM. In addition, the influence of VPD on energy partitioning was stronger under non-drought conditions at AM than at AS at half-hourly scale due to high vegetation cover.

Acknowledgements. This research was jointly funded by the "Hundred Talents" Program, the Project (2010CB833501), Knowledge Innovation Project (KZCX2-YW-432) of the Chinese Academy of Sciences and National Natural Science Foundation of China (Grant No. 30590381, 30721140307).

\section{References}

Baldocchi, D. D., Xu, L., and Kiang N.: How plant functional-type, weather, seasonal drought, and soil physical properties alter water and energy fluxes of an oak-grass savanna and an

BGD

6, 9161-9192, 2009

\section{Surface energy \\ exchanges above two grassland ecosystems}

S. Liu et al.

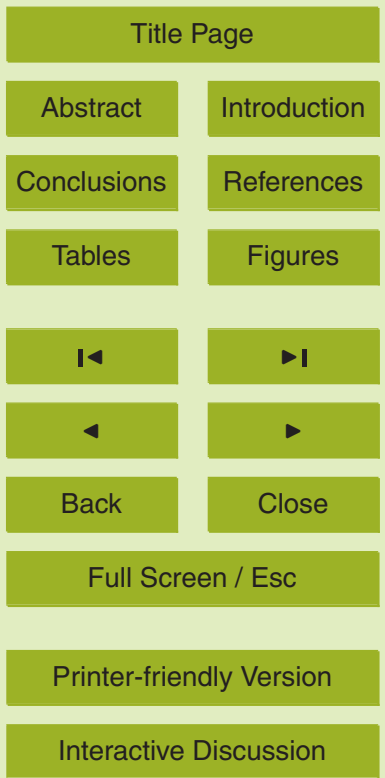


annual grassland, Agr. Forest Meteorol., 123, 13-39, 2004.

Ball, J. T., Woodrow, I. E., and Berry, J. A.: A model predicting stomatal conductance and its contribution to the control of photosynthesis under different environmental conditions, in: Progress in Photosynthesis Research, vol. IV, edited by: Biggins, J., Martinus Nijhof, $5 \quad$ Zoetermeer, The Netherlands, 221-224, 1987.

Beringer, J., Chapin III, F. S., Thompson, C. C., and McGuire A. D.: Surface energy exchanges along a tundra-forest transition and feedbacks to climate, Agr. Forest. Meteorol., 131, 143161, 2005.

Bremer, D. J. and Ham, J. M.: Effect of spring burning on the surface energy balance in a tallgrass prairie, Agr. Forest. Meteorol., 97, 43-54, 1999.

Cai, Y., Li, D. L., Tang, M. C., and Bai, C. Y.: Decadal temperature change over Qinghai-Xizang Plateau in recent 50 years. Plateau Meteorology, 22, 464-470, 2003 (in Chinese).

Cui, Q. H., Jiang, Z. G., Liu, J. K., and Su, J. P.: A review of the cause of rangeland degradation on Qinghai-Tibet Plateau, Pratacult. Sci., 24(5), 20-26, 2007 (in Chinese).

15 Eugster, W., Rouse, W., Pielke Sr., R. A., McFadden, J. P., Baldocchi, D., Kittel, T., Chapin III, F., Liston, G., Vidale, P., Vaganov, E., and Chambers, S.: Land-atmosphere energy exchange in Arctic tundra and boreal forest: available data and feedbacks to climate, Glob. Change Biol., 6 (Suppl. 1), 84-115, 2000.

Fu, Y. L., Yu, G. R., Sun, X. M., Li, Y. N., Wen, X. F., Zhang, L. M., Li, Z. Q., Zhao, L., and Hao, 20 Y. B.: Depression of net ecosystem $\mathrm{CO}_{2}$ exchange in semi-arid Leymus chinensis steppe and alpine shrub, Agr. Forest. Meteorol., 137, 234-244, 2006.

Gu, L., Meyers, T., Pallardy, S. G., Hanson, P. J., Yang, B., Heuer, M., Hosman, K. P., Riggs, J. S., Sluss, D., and Wullschleger, S. D.: Direct and indirect effects of atmospheric conditions and soil moisture on surface energy partitioning revealed by a prolonged drought at a temperate forest site, J. Geophys. Res., 111, D16102, doi:10.1029/2006JD007161, 2006.

Gu, S., Tang, Y. H., Cui, X. Y., Kato, T. M., Du, Y., Li, Y. N., and Zhao X. Q.: Energy exchange between the atmosphere and a meadow ecosystem on the Qinghai-Tibetan Plateau, Agr. Forest. Meteorol., 129, 175-185, 2005.

Hammerle, A., Haslwanter, A., Tappeiner, U., Cernusca, A., and Wohlfahrt, G.: Leaf area controls on energy partitioning of a temperate mountain grassland, Biogeosciences, 5, 421431, 2008, http://www.biogeosciences.net/5/421/2008/.

Hao, Y. B., Wang, Y. F., Huang, X. Z., Cui, X. Y., Zhou, X. Q., Wang, S. P., Niu, H. S., and Jiang, G. M.: Seasonal and interannual variation in water vapor and energy exchange over a typical

\section{BGD}

6, 9161-9192, 2009

\section{Surface energy \\ exchanges above two grassland ecosystems}

S. Liu et al.

Title Page

Abstract

Introduction

Conclusions

Tables

References

Figures

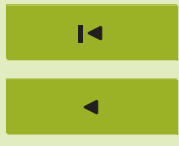

- I

Back

Close

Full Screen / Esc

Printer-friendly Version

Interactive Discussion 
steppe in Inner Mongolia, China, Agr. Forest. Meteorol., 146, 57-69, 2007.

Hu, Z. M., Yu, G. R., Fu, Y. L., Sun, X. M., Li, Y. N., Shi, P. L., Wang, Y. F., and Zheng, Z. M.: Effects of vegetation control on ecosystem water use efficiency within and among four grassland ecosystems in China, Glob. Change Biol., 14, 1609-1619, 2008.

5 Hu, Z., Yu G. R., Zhou, Y. L., Sun, X. M., Li, Y. N., Shi, P. L., Wang, Y. F., Song, X., Zheng, Z. M., Zhang, L., and Li, S. G.: Partitioning of evapotranspiration and its controls in four grassland ecosystems: Application of a two-source model, Agr. Forest Meteorol., 149, 1410-1420, 2009.

Li, S. G., Eugster, W., Asanuma, J., Kotani, A., Davaa, G., Oyunbaatar, D., and Sugita, M.: Energy partitioning and its biophysical controls above a grazing steppe in central Mongolia, Agr. Forest. Meteorol., 137, 89-106, 2006a.

Li, Y. N., Zhao, L., Wang, Q. X., Du, M. Y., Gu, S., Xu, S. X., Zhang, F. W., Zhao, X. Q.: Estimation of biomass and annual turnover quantities of Potentilla froticosa shrub, Acta Agrestia Snica, 14(1), 72-76, 2006b (in Chinese).

Li, Z. Q., Yu, G. R., Wen, X. F., Zhang, L. M., Ren, C. Y., and Fu, Y. L.: Energy balance closure at ChinaFLUX sites, Sci.China Ser. D, 48 (Supp. 1), 51-62, 2005.

Lloyd, J., Grace, J., Miranda, A. C., Meir, P., Wong, S. C., Miranda, B. S., Wright, I. R., Gash, J. H., and Mclntyre, J.: A Simple Calibrated Model of Amazon Rain-Forest Productivity Based on Leaf Biochemical-Properties, Plant Cell Environ., 18(10), 1129-1145, 1995.

Monteith, J. L. and Unsworth, M. H.: Principles of Environmental Physics, 2nd ed., Edward Arnold, London, 291 pp., 1990.

Raupach, M. R.: Influences of local feedbacks on land-air exchanges of energy and carbon, Glob. Change Biol., 4, 477-494, 1998.

Rosset, M., Montani, M., Tanner, M., and Fuhrer, J.: Effects of abandonment on the energy balance and evapotranspiration of wet subalpine grassland, Agr. Ecosyst. Environ., 86, 277286, 2001.

Rosset, M., Riedo, M., Grub, A., Geissmann, M., and Fuhrer, J.: Seasonal variation in radiation and energy balances of permanent pastures at different altitudes, Agr. Forest. Meteorol., 86, 245-258, 1997.

30 Ryu, Y., Baldocchi, D. D., Ma, S., and Hehn T.: Interannual variability of evapotranspiration and energy exchange over an annual grassland in California, J. Geophys. Res., 113, D09104, doi:09110.01029/02007JD009263, 2008.

Shi, P. L., Sun, X. M., Xu, L. L., Zhang, X. Z., He, Y. T., Zhang, D. Q., and Yu, G. R.: Net
BGD

6, 9161-9192, 2009

\section{Surface energy \\ exchanges above two \\ grassland \\ ecosystems}

S. Liu et al.

Title Page

Abstract

Introduction

Conclusions

Tables

References

Figures

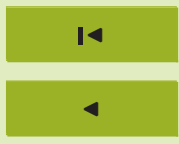

- I

Back

Close

Full Screen / Esc

Printer-friendly Version

Interactive Discussion 
ecosystem $\mathrm{CO}_{2}$ exchange and controlling factors in a steppe-Kobresia meadow on the Tibetan Plateau, Sci. China Ser. D, 49, 207-218, 2006.

Song, M. H., Zhou, C. P., and Ouyang, H.: Simulated distribution of vegetation types in response to climate change on the Tibetan Plateau, J. Veg. Sci., 16, 341-350, 2005.

5 Tian, L., Yao, T. D., Numaguti, A., and Sun, W. Z.: Stable Isotope Variations in Monsoon Precipitation on the Tibetan Plateau, J. Meteorol. Soc. Jpn., 79(5), 959-966, 2001.

Webb, E. K., Pearman, G. I., and Leuning, R.: Correction of flux measurements for density effects due to heat and water vapour transfer, Q. J. Roy. Meteor. Soc., 106, 85-100, 1980.

Wever, L. A., Flanagan, L. B., and Carlson, P. J.: Seasonal and interannual variation in evapotranspiration, energy balance and surface conductance in a northern temperate grassland, Agr. Forest. Meteorol., 112, 31-49, 2002.

Wilczak, J. M., Oncley, S. P., and Stage, S. A.: Sonic anemometer tilt correction algorithms, Bound.-Lay. Meteorol., 99, 127-150, 2001.

Wilson, K. B., Baldocchi, D. D., Aubinet, M., Berbigier, P., Bernhofer, C., Dolman, H., Falge, E., 15 Field, C., Goldstein, A., Granier, A., Grelle, A., Halldor, T., Hollinger, D., Katul, G., Law, B. E., Lindroth, A., Meyers, T., Moncrieff, J., Monson, R., Oechel, W., Tenhunen, J., Valentini, R., Verma, S., Vesala, T., and Wofsy, S.: Energy partitioning between latent and sensible heat flux during the warm season at FLUXNET sites, Water Resour. Res., 38(12), 1294, doi:10.1029/2001WR000989, 2002.

Yang, Y. H. and Piao, S. L.: Variations in grassland vegetation cover in relation to climatic factors on the Tibetan Plateau, Acta Phytoecol. Sin., 30(1), 1-8, 2006 (in Chinese).

Yao, J. M., Zhao, L. Ding, Y. J., Gu, L. L., Jiao, K. Q., Qiao, Y. P., and Wang, Y. X.: The surface energy budget and evapotranspiration in the Tanggula region on the Tibetan Plateau, Cold Reg. Sci. Technol., 52, 326-340, 2008.

Yu, G. R., Wen, X. F., Sun, X. M., Tanner, B. D., Lee, X. H., and Chen, J. Y.: Overview of ChinaFLUX and evaluation of its eddy covariance measurement, Agr. Forest. Meteorol., 137, 125-137, 2006.

Zheng, D. and Yao, T. D.: Uplifting of Tibetan Plateau with its environmental effects, Advances in Earth Science, 21(5), 451-458, 2006 (in Chinese).

30 Zheng, D., Zhang, Q., and Wu, S.: Mountain Geoecology and Sustainable Development of the Tibetan Plateau, Kluwer Academic Publishers, Dordrecht, The Netherlands, 303 pp., 2000.

\section{BGD}

6, 9161-9192, 2009

\section{Surface energy \\ exchanges above two grassland ecosystems}

S. Liu et al.

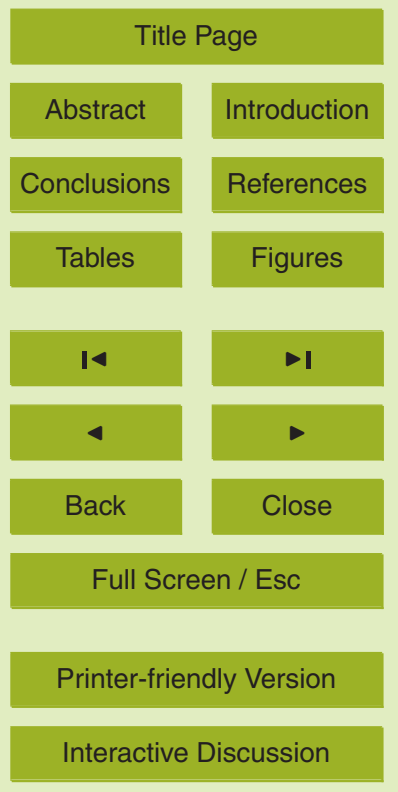


BGD

6, 9161-9192, 2009

\section{Surface energy exchanges above two grassland ecosystems}

Table 1. Site information at the alpine shrub-meadow (AM) and the alpine meadow-steppe (AS) during the measurement periods (January 2003-December 2007 at AM and January 2004-December 2007 at AS).

\begin{tabular}{lcc}
\hline Site & $\mathrm{AM}$ & $\mathrm{AS}$ \\
\hline Location & $37^{\circ} 40^{\prime} \mathrm{N}, 101^{\circ} 20^{\prime} \mathrm{E}$ & $30^{\circ} 51^{\prime} \mathrm{N}, 91^{\circ} 05^{\prime} \mathrm{E}$ \\
Elevation $(\mathrm{m})$ & 3293 & 4333 \\
Mean precipitation $(\mathrm{mm})$ & 580 & 480 \\
Mean temperature $\left({ }^{\circ} \mathrm{C}\right)$ & -2 & 1.3 \\
Canopy height $(\mathrm{cm})$ & 55 & 10 \\
Dominant species & Potentilla fruticosa, & Stipa capillacea, \\
& Kobresia capillifolia, & Carex montis, \\
Grazing & Kobresia humilis & Kobresia pygmaea \\
\hline
\end{tabular}

S. Liu et al.

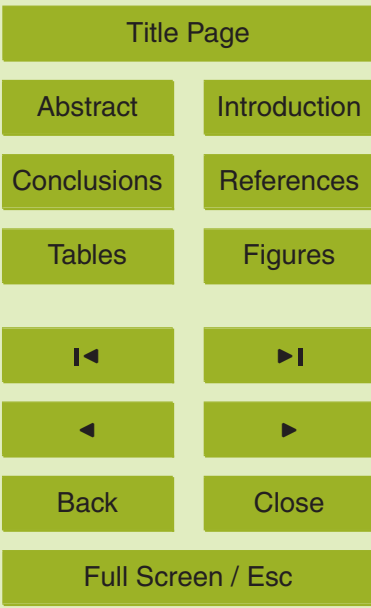

Printer-friendly Version

Interactive Discussion 


\section{BGD}

6, 9161-9192, 2009

\section{Surface energy exchanges above two grassland \\ ecosystems}

Table 2. Inter-annual comparison of air temperature at $2.2 \mathrm{~m}\left(T_{\mathrm{a}}\right)$, precipitation, NDVI, the Bowen ratio $(\beta)$, canopy surface conductance $\left(g_{\mathrm{s}}\right)$, and the decoupling factor $(\Omega)$ in the growing season at $A M$ and $A S$.

\begin{tabular}{cccccccc}
\hline Site & Year & $\begin{array}{c}T_{\mathrm{a}} \\
\left({ }^{\circ} \mathrm{C}\right)\end{array}$ & $\begin{array}{c}\text { Precipitation } \\
(\mathrm{mm})\end{array}$ & NDVI & $\beta$ & $\begin{array}{c}g_{\mathrm{s}} \\
\left(\mathrm{mm} \mathrm{s}^{-1}\right)\end{array}$ & $\Omega$ \\
\hline AM & 2003 & 6.44 & 445.70 & 0.57 & 0.64 & 8.60 & 0.55 \\
& 2004 & 6.18 & 418.70 & 0.57 & 0.68 & 8.50 & 0.52 \\
& 2005 & 6.38 & 454.40 & 0.59 & 0.66 & 8.70 & 0.55 \\
& 2006 & 7.05 & 455.10 & 0.58 & 0.64 & 9.90 & 0.59 \\
& 2007 & 7.10 & 394.10 & 0.60 & 0.55 & 10.40 & 0.59 \\
AS & 2004 & 8.99 & 512.30 & 0.27 & 0.37 & 9.90 & 0.66 \\
& 2005 & 9.02 & 426.90 & 0.27 & 0.51 & 6.80 & 0.60 \\
& 2006 & 9.63 & 207.00 & 0.20 & 0.66 & 4.70 & 0.54 \\
& 2007 & 9.91 & 409.50 & 0.21 & 0.60 & 6.10 & 0.54 \\
\hline
\end{tabular}

S. Liu et al.

\section{Title Page}

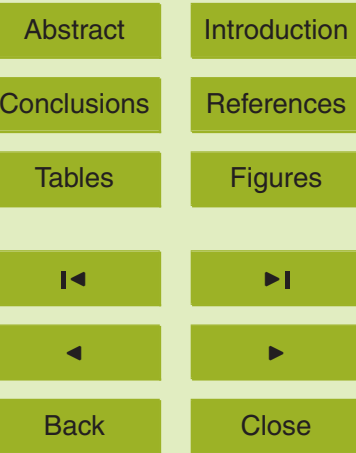

Full Screen / Esc

Printer-friendly Version

Interactive Discussion 


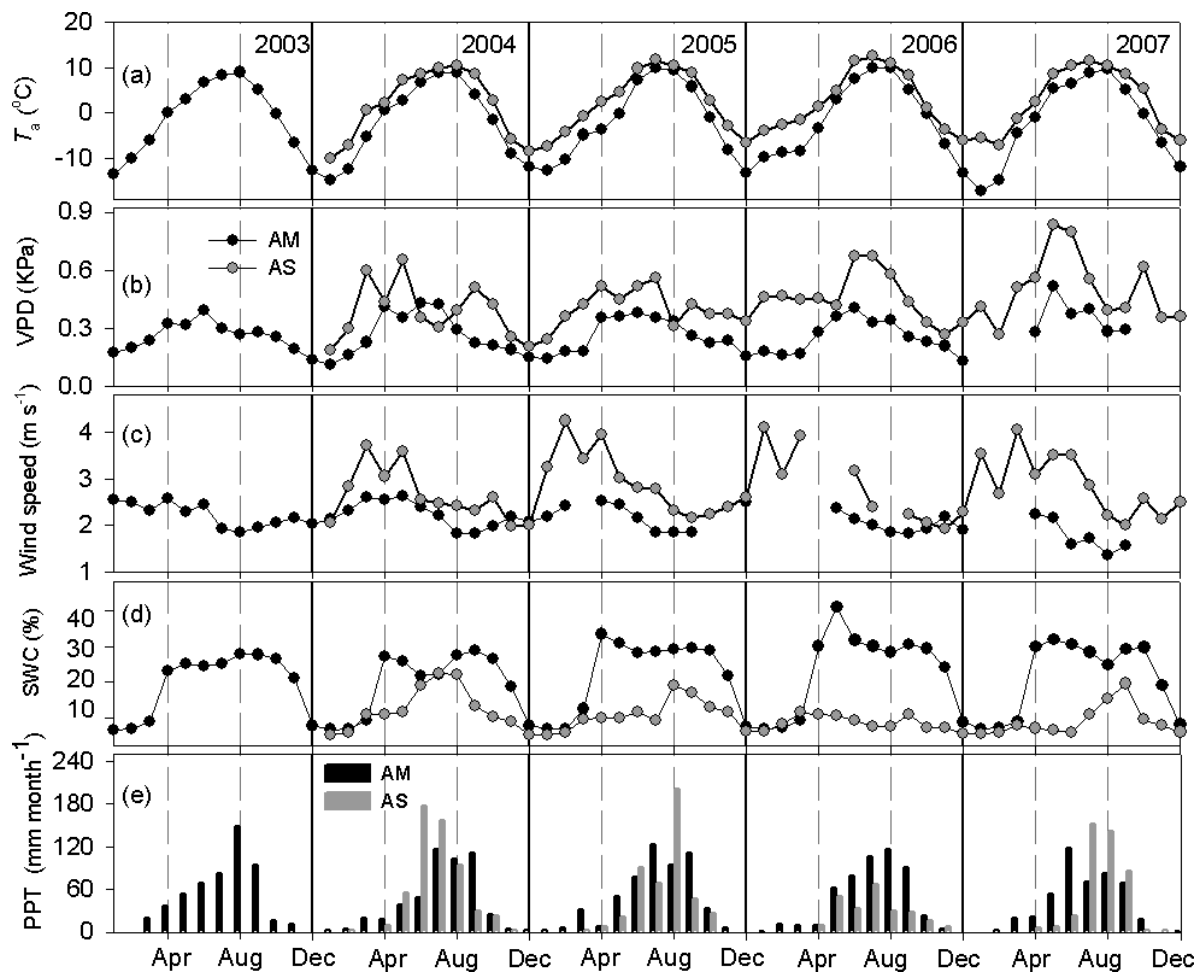

Fig. 1. Variation of (a) monthly average of daily air temperature $\left(T_{\mathrm{a}}\right)$, (b) monthly average of daily VPD, (c) monthly average of daily wind speed, (d) monthly average of daily volumetric soil water content at $20-\mathrm{cm}$ depth (SWC), and (e) monthly sum of precipitation (PPT) at the shrub-meadow ecosystem (AM) and the alpine meadow-steppe ecosystem (AS).
BGD

6, 9161-9192, 2009

\section{Surface energy exchanges above two grassland ecosystems}

S. Liu et al.

\section{Title Page}

\section{Abstract}

Conclusions

Tables

14

Back
Introduction

References

Figures

$\rightarrow 1$

Close

\section{Full Screen / Esc}

Printer-friendly Version

Interactive Discussion 
BGD

6, 9161-9192, 2009

\section{Surface energy exchanges above two grassland ecosystems}
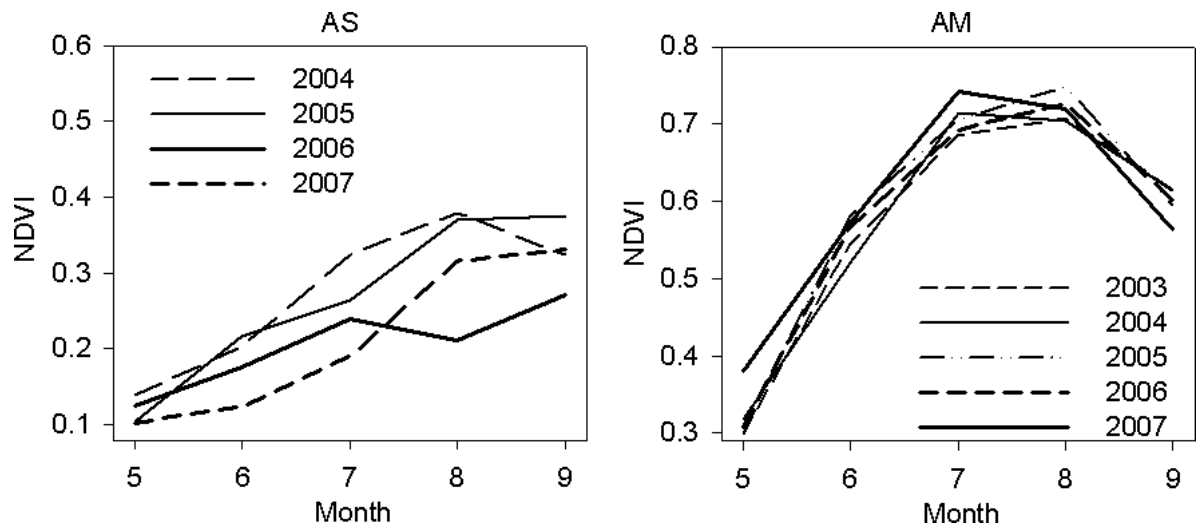

S. Liu et al.

Title Page

Abstract

Introduction

Conclusions

References

Tables

Figures

Fig. 2. Seasonal and inter-annual variations in NDVI at the shrub-meadow ecosystem (AM) and the alpine meadow-steppe ecosystem (AS).

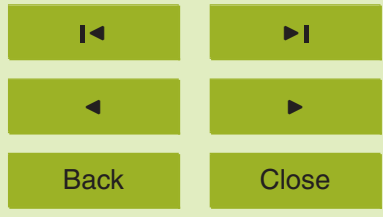

Full Screen / Esc

Printer-friendly Version 


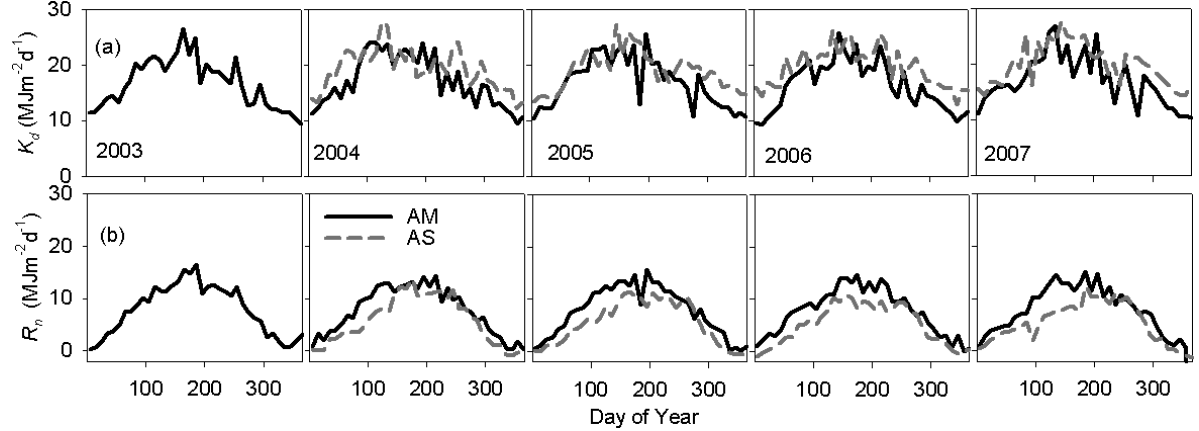

Fig. 3. Seasonal and inter-annual variations in the ground solar radiation $\left(K_{\mathrm{d}}\right)$ and net radiation $\left(R_{\mathrm{n}}\right)$ at the shrub-meadow ecosystem (AM) and the alpine meadow-steppe ecosystem (AS): (a) downward solar radiation $\left(K_{\mathrm{d}}\right)$ and (b) net all-wave radiation $\left(R_{\mathrm{n}}\right)$.

\section{Surface energy exchanges above two grassland ecosystems}

S. Liu et al.

\section{Title Page}

\section{Abstract}

Introduction

Conclusions

References

Tables

Figures

14

$\rightarrow 1$

4

Back

Close

\section{Full Screen / Esc}

Printer-friendly Version

Interactive Discussion 
BGD

6, 9161-9192, 2009

\section{Surface energy exchanges above two grassland ecosystems}

S. Liu et al.

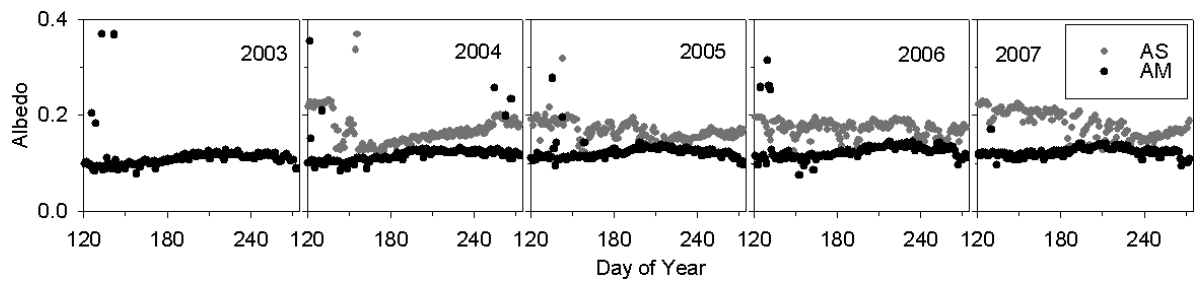

Fig. 4. Seasonal and inter-annual variation in the daily albedo during the growing seasons at AM and AS.
Title Page

\section{Abstract}

Conclusions

\section{Tables}

14

4

Back
Introduction

References

Figures

- I

$>$

Close
Full Screen / Esc

Printer-friendly Version

Interactive Discussion 
BGD

6, 9161-9192, 2009
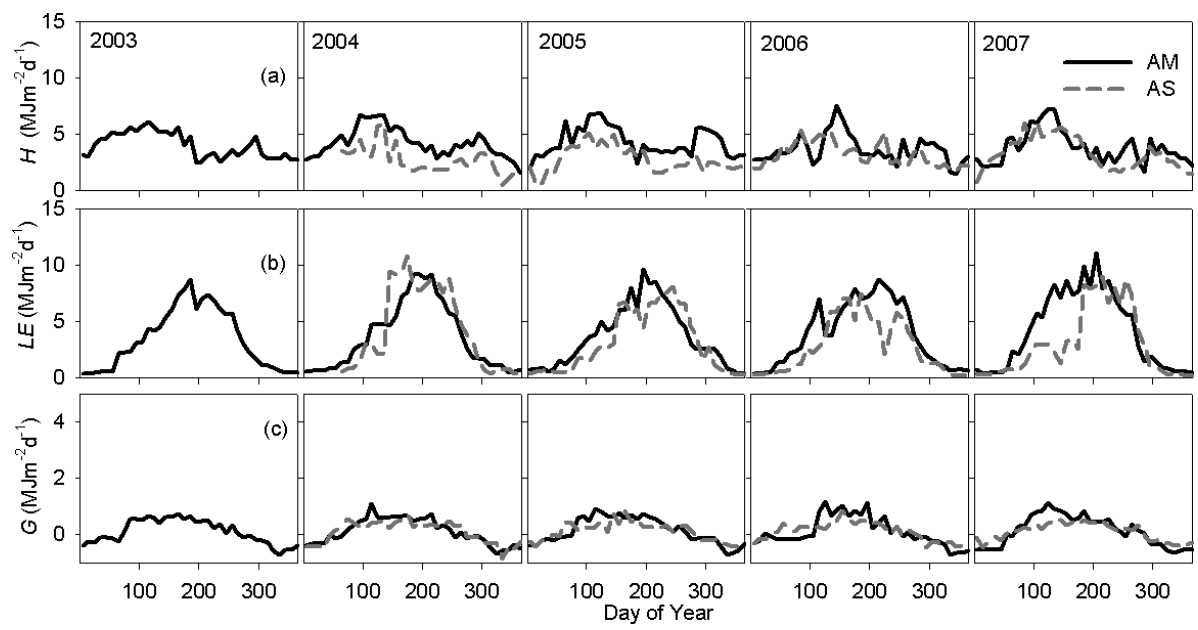

\section{Surface energy exchanges above two grassland ecosystems}

S. Liu et al.

Title Page

Abstract

Conclusions

Tables

14

4

Back

Full Screen / Esc

Printer-friendly Version

Fig. 5. Seasonal and inter-annual variations in (a) sensible heat $(H)$, (b) latent heat $(L E)$, and (c) soil heat $(G)$ at AM and AS. 
BGD

6, 9161-9192, 2009

\section{Surface energy exchanges above two grassland ecosystems}

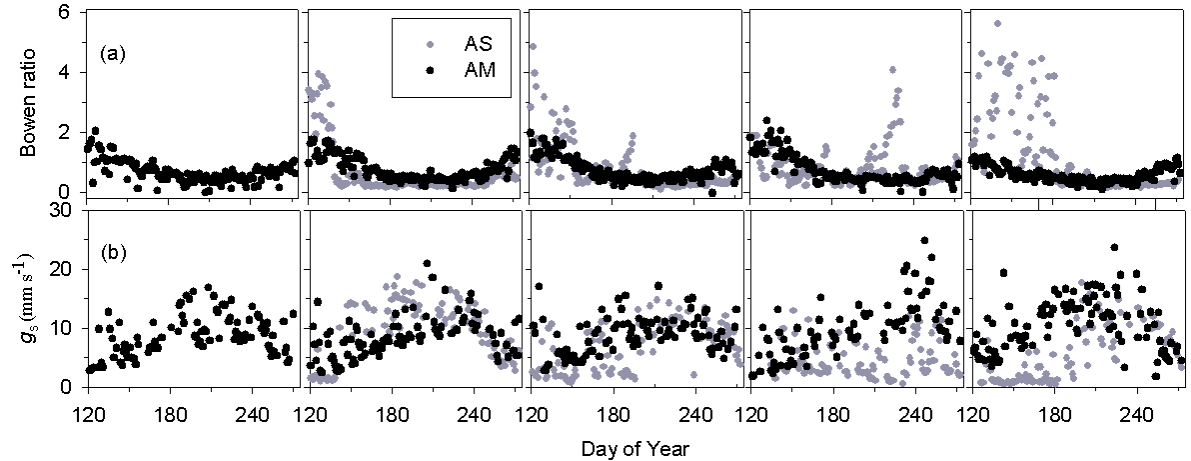

S. Liu et al.

Title Page

Abstract

Introduction

Conclusions

References

Tables

Figures

Fig. 6. Seasonal and inter-annual variations in (a) the daily Bowen ratio $(\beta)$ and (b) surface conductance $\left(g_{\mathrm{s}}\right)$ during the growing season at AM and AS.
14

4

Back
$>1$

$>$
Full Screen / Esc

Printer-friendly Version

Interactive Discussion 
BGD

6, 9161-9192, 2009

\section{Surface energy exchanges above two grassland ecosystems}
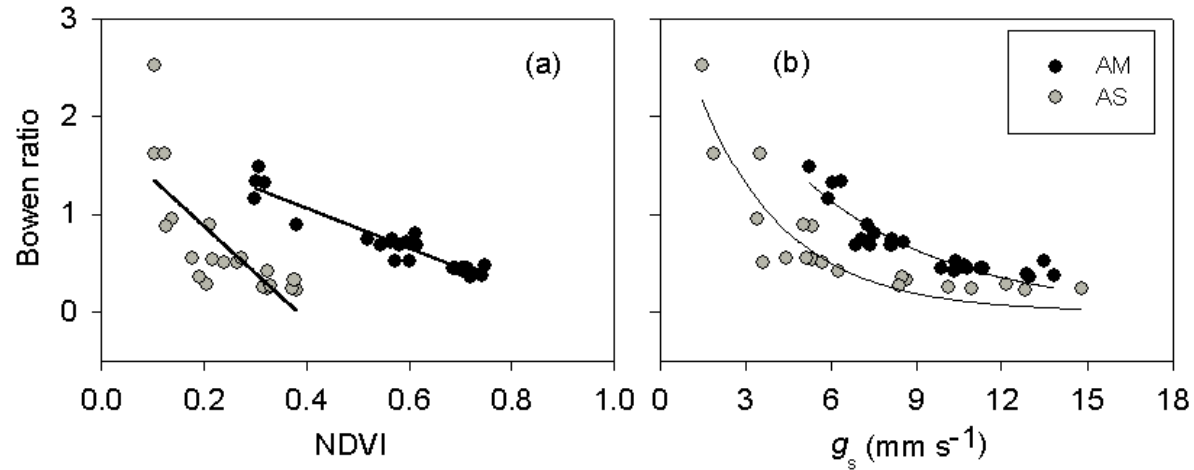

Fig. 7. Relationship between monthly average Bowen ratio $(\beta)$ and (a) NDVI, (b) surface conductance $\left(g_{\mathrm{s}}\right)$ at AM and AS.
S. Liu et al.

Title Page

Abstract

Introduction

Conclusions

References

Tables

Figures

14

$\rightarrow$ I

4

Back

Close

Full Screen / Esc

Printer-friendly Version

Interactive Discussion 


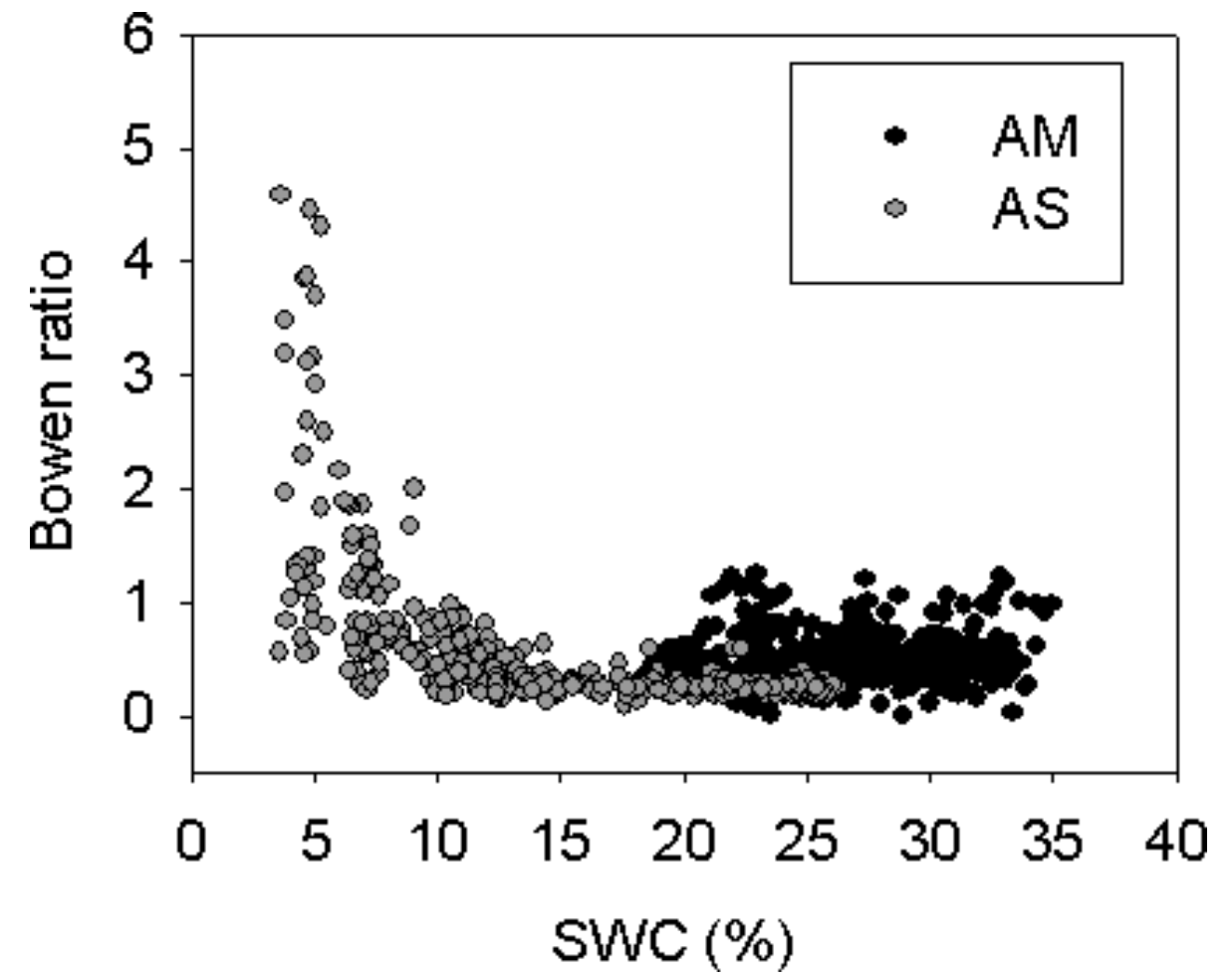

Fig. 8. Relationship between the daily average Bowen ratio $(\beta)$ and volumetric soil water content (SWC) at AM and AS.

\section{BGD}

6, 9161-9192, 2009

\section{Surface energy exchanges above two grassland ecosystems}

S. Liu et al.

\section{Title Page}

Abstract

Conclusions

Tables

14

4

Back

Full Screen / Esc

Printer-friendly Version 
BGD

6, 9161-9192, 2009

\section{Surface energy exchanges above two grassland ecosystems}
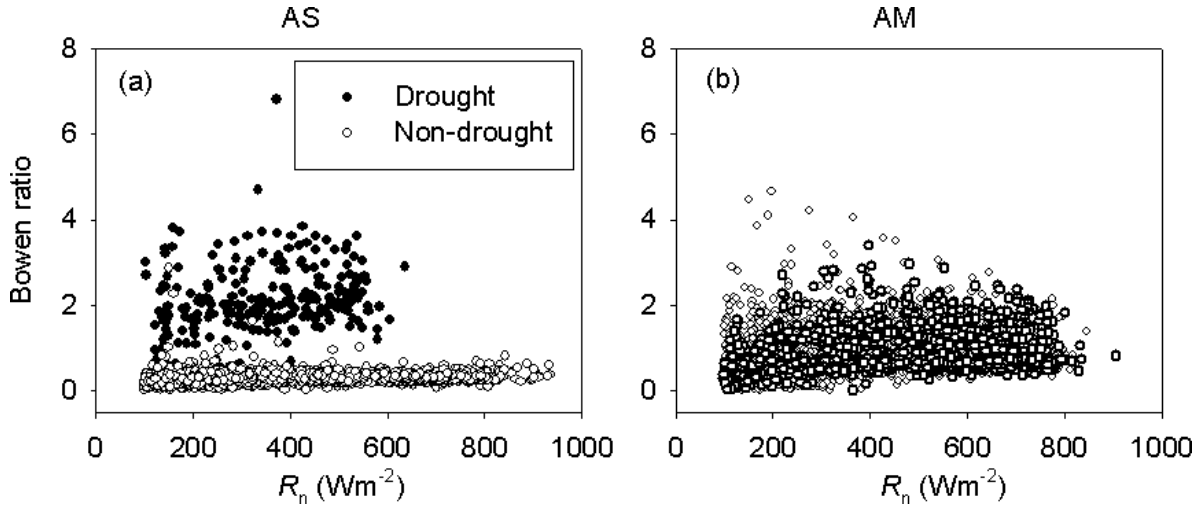

Fig. 9. Effect of net radiation $\left(R_{\mathrm{n}}\right)$ on the Bowen ratio $(\beta)$ at (a) AS and (b) AM. ("non-drought" indicates SWC $>15 \%$, and "drought" indicates SWC $<8 \%$, the same below).
S. Liu et al.

Title Page

Abstract

Introduction

Conclusions

References

Tables

Figures

14

$\rightarrow$ I

4

Back

Close

Full Screen / Esc

Printer-friendly Version

Interactive Discussion 


\section{BGD}

6, 9161-9192, 2009

\section{Surface energy exchanges above two grassland ecosystems}
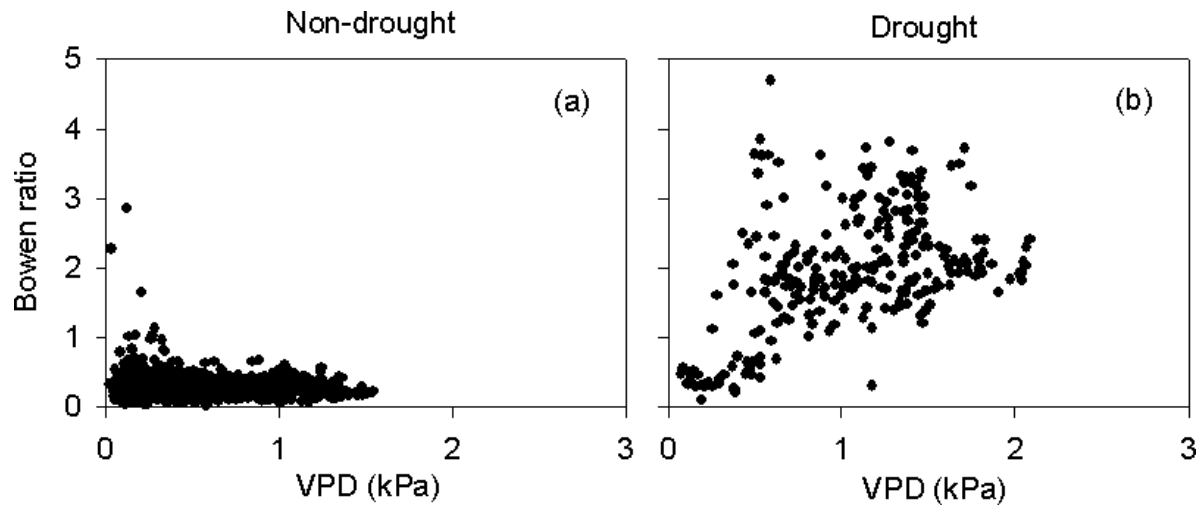

S. Liu et al.

Fig. 10. Effect of VPD on the Bowen ratio $(\beta)$ under (a) nondrought and (b) drought conditions at AS.

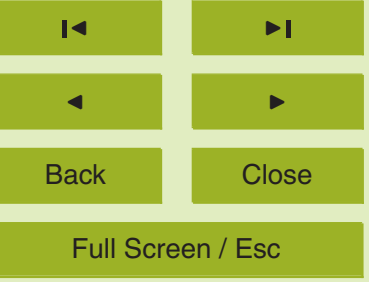

Printer-friendly Version

Interactive Discussion 
BGD

6, 9161-9192, 2009

\section{Surface energy exchanges above two grassland ecosystems}
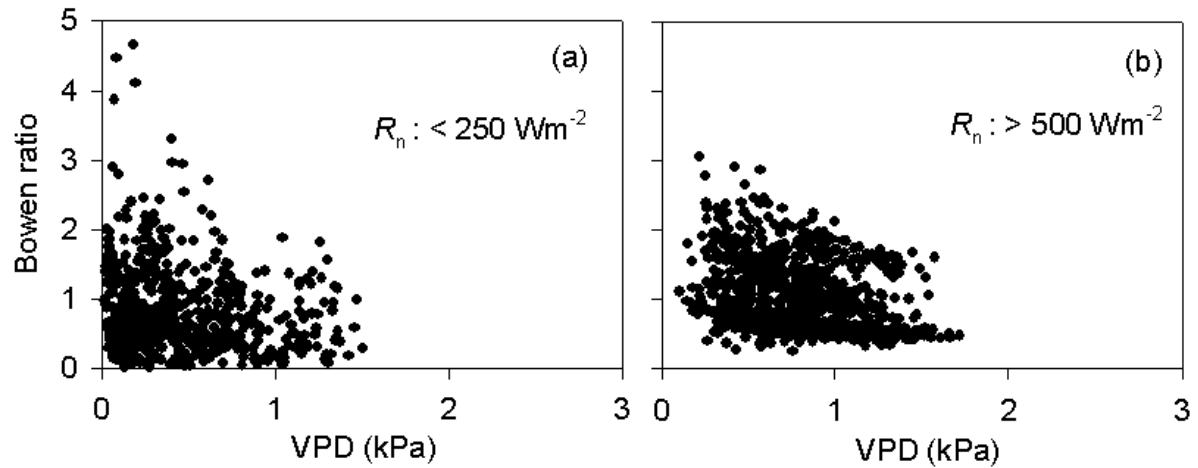

Fig. 11. Effect of VPD on the Bowen ratio $(\beta)$ at two levels of net radiation $\left(R_{\mathrm{n}}\right)$ at $\mathrm{AM}$.
S. Liu et al.

Title Page

Abstract

Conclusions

Tables

14

4

Back

Full Screen / Esc

Printer-friendly Version

Interactive Discussion
References

Figures

$>1$

$>$

Close 
BGD

6, 9161-9192, 2009

\section{Surface energy exchanges above two grassland ecosystems}
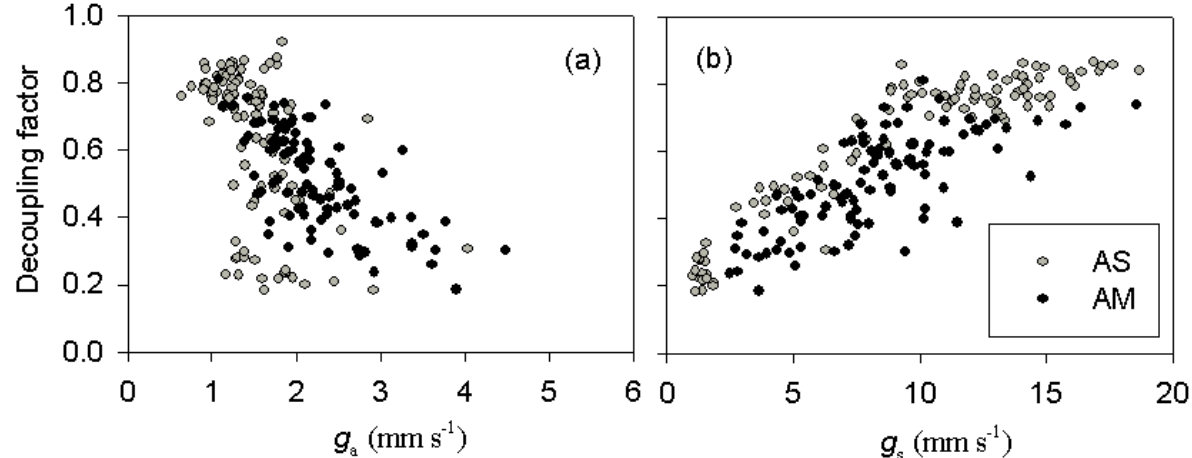

S. Liu et al.

Title Page

Abstract

Introduction

Conclusions

References

Tables

Figures

Fig. 12. Variation of the decoupling factor $(\Omega)$ versus (a) aerodynamic conductance $\left(g_{\mathrm{a}}\right)$ and (b) canopy surface conductance $\left(g_{\mathrm{s}}\right)$ in the growing season of 2004 at AM and AS.

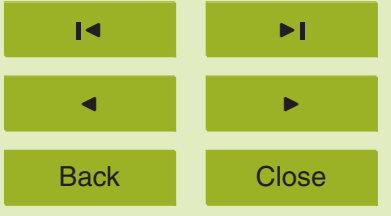

Full Screen / Esc

Printer-friendly Version 